\title{
STUDY ON THE PROSPECTS OF PROMOTING DHAKA CLOTH PRODUCTION IN NEPAL
}

\author{
Erene Shrestha*
}

\begin{abstract}
Research Study on the prospects of promoting Dhaka cloth production in Nepal is aimed to explore the present situation and the future prospects of the expansion of Dhaka industry in Nepal. Dhaka cloth is swivel woven through hand loom traditional cloth. Its manufacturing is concentrated mainly in Kahtmandu valley, Pokhara and Palpa and in recent years in the hills of eastern Nepal Therathum etc. The research is conducted taking interviews with the owners of Palpali Dhaka Udyog, Therathume Dhaka Udyog Dhaka weaves, Mahaguthi, Dhanakuta sisters entrepreneurs in Kupondole and visiting and interviewing in Gharelu Udyog in Tripureswar and visiting some of the retail shops of Kathmandu valley, where different types of Dhaka are sold from different parts of the countries. A questionnaire is developed to be answered by the retail sellers and another questionnaire was developed by the Dhaka factory owners. The questionnaire include mostly with their production purchases, sales, weaving techniques, yarn used dyeing methods etc. Secondary literature and information are hardly used in this research paper.

Possibilities of prospects for the expansion of exports lie in modernization in certain segment of the sectors to ensure the right quality of fabrics used in the garments extension of technical assistance, training and modern techniques and designs. Dhaka weaves export the products in Norvey, Switzerland, Japan, America etc. In the past, it also used to supply in royal family. There is also a good prospect for selling of efficient manufacturing units in the form of export oriented joint ventures in response to the condisreable opportunities available in dynamic export market. Handloom units of the country substituted by the big mills and factories can be organized and modernized for export oriented handloom cloth production if well planned improvement in loom yarn consumption, methods and designs are made.
\end{abstract}

\section{INTRODUCTION}

Dhaka is a traditional cloth produced in Nepal since long time back. This multi coloured swivel woven cloth is used for making caps and jackets for men, and shawl and blouse for women. A Nepali Daura-suruwal dress for men is also made out of this cloth for special occasions like marriage. However it is mainly used for making caps and shawls. Production of Dhaka is believed to have increased during last two decades mainly due to popularity of Dhaka caps among men in the hills and Tarai (Shrestha 1995).

Export made out of Dhaka is also increasing in readymade garments. It is reported that Nepalese Dhaka garments are popular especially in western

\footnotetext{
* Associate Professor, Padma Kanya Campus, Tribhuvan University, Kathmandu, Nepal
} 
countries and Japan but the possibility of increasing the exports of Dhaka garments is yet to be fully explored.

The specialty of Dhaka cloths is woven through handlooms by using multi-coloured cotton yarn. In the past it was used to be manufactured at household level in Kathmandu valley involving the family members in its production. But in the recent years, several cottage and small industrial units registered in the cottage industry have been involved in the production of Dhaka cloth. Its manufacturing is concentrated mainly in Kathmandu valley, Pokhara, Palpa and in the eastern Nepal.

Another important aspect of Dhaka cloth is that, being a handloom manufactured production, it is a highly labour intensive industry. Growth in the production of Dhaka cloth results into immediate growth in the employment opportunities. Moreover women have been generally found involved in the operation of Dhaka producing hand looms. Therefore, promotion of this industry has a far reaching implication on creating jobs for women.

\section{MEANING AND CONCEPT OF DHAKA}

The fixed origin of the name Dhaka is unknown. The fine texture of Dhaka cloth suggests similarities to the famous Dhaka muslin. Others believe that the name was given to the cloth simply because many items like cloth or thread came to Nepal through Dhaka (formerly Dacca). The sound of the Nepali words for thread "Dhago" or for cover "Dhakun" are also similar to Dhaka (Shrestha 1995).

The most remarkable feature of Nepalese cotton weaving can be seen in the variety of patterned colorful caps or topis, the traditional headgear for men a product of the skill and inventiveness of Limbu and Rai women in the Kosi hill area who weave cotton in the strips from which the caps are made. Limbus and Rais are believed to be descendants of the ancient in the ancient Kirats, the earliest inhabitants of Nepal.

Nepalese Dhaka cloth is woven in swivel weave style. Swivel designs are made on a loom that has an attachment holding tiny shuttles. The fabric is woven so the shuttles and extra yarns are above the ground fabric. Each shuttle carrying the extra yarn goes four times around the warp, yarns in the ground fabric and then yarn is carried along the surface to the next spot. The yarn is sheared off between the spots.

Swivel dot fabrics, clipped dot fabrics and the larger clipped spot fabrics may use either side of the fabric as the right side. Dotted Swiss can also be an applied design. The dots may be printed or for a three dimensional effect flocked or made with expanded foam. Comparison of several different types of dotted Swiss is an interesting exercise in deterring the serviceability of fabrics.

\section{SWIVEL WEAVE}

Swivel dot designs are made on a loom that has attachment holding tiny shuttles. The fabric is woven so the shuttles and extra yarns are above the ground fabric. Each shuttle carrying the extra yarn goes four times around the warp yarns in the ground fabric and then the yarn is the ground fabrics and then the yarn is 
carried along the surface to the next spot. The yarn is sheared off between the spots. Swivel dot fabrics are rarely seen in the United States, except as imported designer fabrics (Shrestha 1995).

Swivel dot fabrics, clipped dot fabrics, and the larger clipped spots fabrics may use either side of the fabric as the right side. Fashion may dictate which side is correct or personal preference may determine which side to use.

Dotted Swiss may also be an applied design. The dots may be printed or for a three dimensional effect flocked or made with expanded foam. A comparison of several different types of dotted Swiss is an interesting exercise in determining the serviceability of fabrics.

Swivel weave is used by Swiss cloth manufactures. Nepalese Dahaka cloth is also woven in swivel weave style. The yarns to be used in each pattern are weaved on quills and place in small shuttles. These shuttles are strategically located at each point where the design occurs. The pattern mechanism causes a shed to be made, and the shuttle carries the yarn through the shed distance of the pattern.

It is repeated for each row of the design. Between repeats the extra filling floats on the back of fabric and is cut away after the weaving is completed.

The swivel process permits the weaving of different colures in the same raw, because each figure has its own shuttle. In fabrics with small designs the swivel will save material and give figures a prominent, raised appearance. This method fastens the yarn securely as each figure is completed and it cannot pull out. There is almost on fabric made by this process in United States, by several swiss manufacturers utilize it.

Swivel weaves can be recognized by the fact that the name of face and back. It appears to go around a group of warn yarns several times.

Though the Dhaka cloth industry has not flourished tremendously as other industries like garment, carpet etc, the number of women workers' condition in Dhaka cloth production has been changed. Now more and more women workers are involved in Dhaka cloth production unit as well as Dhaka cloth stitching garments. The number of only Dhaka cloth shops and some industries are totally run by women entrepreneurs. Dhaka cloth weaving sections are also involving more women weavers.

\section{OBJECTIVES OF THE STUDY}

The researcher selected following objective for the study:

a. To examine the weaving techniques, patterns, design, yarns and dyes used by the traditional Dhaka weavers

b. To take account of Dhaka production in Nepal - number of handlooms used in producing Dhaka, annual production of different types of this fabric number of persons (men/women) engaged in its production district/town where its is mainly manufactured production trend during the last 5 years and the export trend during the same period etc.

c. To examine problems faced by weavers of Dhaka cloth 
d. To explore the possibility of increasing the export potential of Dhaka fabrics by concentrating the study on the quality aspect of this traditional fabric

e. To examine the institutional support that is received by Dhaka weavers and exploring the possibility of such support i.e., providing softer bank loans, making available of yarn and dyes, assisting the weavers in establishing contacts with importers located in potential importing countries etc.

f. To examine the feasibility of increasing the participation of women in the production of Dhaka keeping in view that it is a cottage based industry. Encouraging women to engage in this work could enhance their earning capacity thereby uplifting their status in the family and the society.

\section{SAMPLING PROCEDURE}

It has not been possible to cover all the Dhaka factories all over Nepal. So, about 4 factories inside the valley were visited and about 12 retail main shops owners interviewed. The owner of Palpali Dhaka Udyog was also interviewed. A Textile unit Dhaka Kapada in Gharelu Udyog and have now opened Dhaka Udoyog in Kathmandu were also interviewed. Dhaka weaves and Mahaguthi and Dhanakuta sisters entrepreneurs were also interviewed.

\section{DATA COLLECTION PROCEDURE}

A questionnaire was developed to be answered by the Dhaka retail sellers and another questionnaire was also developed to be answered by the Dhaka factory owners. Some of the questions were asked to some women factory workers about their problems. The questionnaire included mostly with their production, purchases, sales etc. The interview techniques employed in this study were directed and semi directed and this study adopts observation techniques within the town and the village as well.

(i) Nature of type of Dhaka factory

(ii) Household activities associated with the housewives

(iii) Participation activities associated with the housewives

(iv) Working methods and distribution system and others.

Key information was taken for the following aspects of Dhaka clothing:

(i) History of Dhaka cloth

(ii) Information as normal size with the changing role of women in the study area

(iii) Problems of women and prospects associated with Dhaka entrepreneurships' and weavers

(iv) Export policy and prospects

(v) Recent developments and change in the study area. 


\section{RESULTS}

Only one Dhaka textile industry of Kusmi Sere Village produces Dhaka textile industry, of Kusmi Sere Village produces Dhaska textile and it is used in making Dhaka topi and the industry itself manufacturing topi and sale distribution. This industry in 2037/2038 produced and distributed 3200 Dhaka caps. Keeping this fact in mind, one Dhaka topi industry in each district was potentially feasible. The proposed unit project was supposed to produce 1550 meter Dhaka cloth and this can prepare average 10,850 Dhaka caps.

KHARDEP- Koshi Hill Area Rural Development Programme also supported for Dhaka weaving projects. It was initiated in September, finally implemented in December 1979 with the financial support of the government of UK the command area of the project includes hilly, districts of Koshi Zone in the eastern Nepal namely Dhankuta, Bhojpur, Terhathum and Sankhwasabha. There are also other activities too carried on by KHARDEP project. Some of the Dhaka sellers said that it is called Khardep Dahaka what we call Terhathume Dhaka modern Dhaka.

An evaluative study of TRUGA project and methodology regards women's participation and benefits TRUGA, the acronym for Training developed by the ILO to promote and support employment and income generation activities in the rural areas.

Although throughout Nepal, factory made cloth has replaced much of the traditional hand woven material for clothing the demand for the individually made Dhaka cloth has continued. Most men invest in a new topi for special occasions such as harvest festival, the new year of Dasain often something unusual is sought, for example, a commission to design a topi with a new pattern to be worn at a wedding. Sometimes a bridegroom wills were full national dress made from Dhaka cloth. At his own wedding His Majesty king Birendra of Nepal wore such a suit with silver branding (Simha 1970).

The demand for traditional blouses and shawls is not as great as that for topis, although the style of the blouse remains unchanged, many women use factory made sometimes handprinted cotton instead of hand woven Dhaka cloth. Among the Limbu weavers, the most popular material is dark red velvet. However at wedding ceremonies, particularly among the more affluent, the bride will often wear a Dhaka-cloth blouse and will be given a length of Dhaka cloth as part of her dowry. The traditional blouse, the chaubandi, as the name indicates is tied at four places (chau; means and means four; bandi; tie). The ties of this very practical garment allow for variation in size. The two parts of the front of the blouse overlap so the right side crosses over the left, and each is tied near the armhole and at the waist. The cut of the blouse is in fact similar to that of the blouse is in fact similar to that men's garment but it reaches only to the waist. Urban areas the blouse is worn with an Indian style sari, but in most rural areas women wear a lungi a tubular skit (about $80 \times 200 \mathrm{~cm}$ ) or a wraparound length of cloth $(80 \times 500 \mathrm{~cm}$ or more) and a hand - woven cotton waistband, patuka $(40 \mathrm{~cm}$ wide and at least $300 \mathrm{~cm}$, long) several times thus supporting the back and at the same time providing pockets for all kinds of valuables in its various folds. Recent 
research has confirmed that this patuka by supporting the lumosacral spine could be one of reasons for the low incidence of mechanical back pain, the patuka wearing population of Nepal.

Tansen Palpa has become the centre of Dhaka cloth industry in Nepal for several decades. There are large numbers of handlooms which produce Dhaka. More than 70 percent of the workers are women. However in the recent years, the imports of cheap Dhaka from nearby Indian town of Gorkhpur has been posing a serious threat to Dhaka industry of our hilly districts. It is reported that various problems like unsuitable work place, lack of transportation facilities, lack of health facilities, lack of opportunity for education, lack of laborer's quarter facility, low wage, lack of training center laborers prevented from the weaving patterns of their choice, lack of child care center, lack of Tiffin facility, lack of job security (not a single woman was found permanent stay of the industry) etc. are faced by Dhaka factory according to Subhadra Banjade's thesis report (Banjade 1998).

Table 1. Dhaka Textile Production in Nepal

\begin{tabular}{|c|c|c|c|c|}
\hline $\begin{array}{c}\text { Re- } \\
\text { tailer's } \\
\text { shop }\end{array}$ & $\begin{array}{c}\text { Place of } \\
\text { Production }\end{array}$ & Items Sold & $\begin{array}{l}\text { Price/meter } \\
\text { in Rs. }\end{array}$ & $\begin{array}{c}\text { Profit } \\
\text { Percentage }\end{array}$ \\
\hline 1 & $\begin{array}{l}\text { Palpa, Pokhara } \\
\text { Terhathum }\end{array}$ & $\begin{array}{l}\text { Shawls, Chole, topi } \\
\text { Labeeda Suruwal }\end{array}$ & $120-125$ & $15-20 \%$ \\
\hline 2 & $\begin{array}{l}\text { Thankot, Lamkhel, } \\
\text { Palpa, Pokhare, } \\
\text { Terhathum, } \\
\text { Dhankuta (in past) }\end{array}$ & $\begin{array}{l}\text { Child dress for } \\
\text { Pasni, Sari, cholo, } \\
\text { shawl, labeda, } \\
\text { Suruwal }\end{array}$ & $50-150$ & $10-20 \%$ \\
\hline 3 & $\begin{array}{l}\text { Ghattekulo,Bhakta } \\
\text { pur, Thankot }\end{array}$ & $\begin{array}{l}\text { Caps, Shawls, } \\
\text { Muffler, Neck tai, } \\
\text { Waist coat, blouse }\end{array}$ & $50-150$ & $9-10 \%$ \\
\hline 4 & $\begin{array}{l}\text { Palpa, Balambu, } \\
\text { Thankot }\end{array}$ & $\begin{array}{l}\text { Shawls, caps, } \\
\text { Blouse, Daura } \\
\text { Suruwal } \\
\end{array}$ & $\begin{array}{l}100-125 \\
200-300\end{array}$ & $10-15 \%$ \\
\hline 5 & Kupondol, Patan & $\begin{array}{l}\text { Muffler, Shawles, } \\
\text { Waist Coats Scart, } \\
\text { Table Mats, } \\
\text { Bi-products-toilet } \\
\text { bags, Money } \\
\text { purse, Lamp } \\
\text { Shades, floor } \\
\text { cushions }\end{array}$ & $\begin{array}{c}\text { 300-900 } \\
\text { Exportable }\end{array}$ & $15-20 \%$ \\
\hline 6 & $\begin{array}{l}\text { Terbatum, } \\
\text { Dhankuta, } \\
\text { Liltpur }\end{array}$ & $\begin{array}{l}\text { Large and small } \\
\text { shawle, Muffler, } \\
\text { recently sari, } \\
\text { Cushion cover, } \\
\text { waist coat Jacket, } \\
\text { skirt, bedcover, } \\
\text { Nepali bages, Tea }\end{array}$ & $600-700$ & $15-20 \%$ \\
\hline
\end{tabular}




\begin{tabular}{|c|l|l|c|c|}
\hline & & $\begin{array}{l}\text { coffee, file purse } \\
\text { etc. }\end{array}$ & & \\
\hline 7 & $\begin{array}{l}\text { Palaps, } \\
\text { Terhathume, } \\
\text { Pokhara }\end{array}$ & $\begin{array}{l}\text { Daure Suruwal, } \\
\text { Sakkali Dhake } \\
\text { Shawles Blouses }\end{array}$ & $75-500$ & $15-20 \%$ \\
\hline 8 & $\begin{array}{l}\text { Gharelu } \\
\text { Kathmandu, Bara, } \\
\text { Dhanusha, } \\
\text { Pokhara, Palpa }\end{array}$ & $\begin{array}{l}\text { Curtains, sofa } \\
\text { covers, Photo } \\
\text { frames, blouses, } \\
\text { Shawls, bags, } \\
\text { Daura Surwal,caps }\end{array}$ & $80-300$ & $10-15 \%$ \\
\hline
\end{tabular}

Source: Report of study on the prospects of promoting Dhaka cloth discussion production in Nepal 1995.

It is found out that traditional dresses made up of Dhaka are blouses, shawls, labeda suruwal, children's bhoto suruwal and topi (widely used in Nepal). The 'Sakkali' or pure Dhaka is best one and of higher price and there is low priced Dhaka too, some of which come in the category of 'Nakkali' Dhaka. There is hardly any change in the traditional Sakkali Dhaka, which is best woven in Palpa.

But Terhathum Dhaka with some modern designs are in fashion these days. The shawls used in Kurta Salwar, jackets, waist coats, cushions, bags, used in sarees are preferred by people. Foreigners like the Dhaka made mufflers, housecoats and jackets.

Some cheaper Dhaka clothes can be adopted for interior decoration i.e. bedspreads, upholstery, pillow cases beavier, Terhathum Dhaka too still in refined designs are exportable. The varieties of the productions can be manufactured with this type of Dhaka.

The 'Sakkali' Dhaka has its own traditional value. The selling if this type of Dhaka increases during season of marriage, during "Pasni time", and during winter season. The sale of Dhaka caps are highest than the other production. Generally in marriage season, high standard people buy Dhaka cloths to make Dhaka daura suruwal blouses shawls to present to brides and bridegrooms by relatives, villagers, low standard people usually buy cheap Dhaka clothes which may not be Sakkali Dhaka. 'Sakkali' is a term used for original.

Cottage and small industries organizers have tried to mix up western Dhaka weavers interaction in their training. But they were successful to take the western group in the east, but they could not sale the eastern group to the west for some other reason.

Here in Kathmandu valley the Dhaka industries are scattered here and there but in Lubhu, Lilitpur almost every household has its loom and in some areas there are factories too.

Table 2. Dhaka Clothes Estimated Production

\begin{tabular}{|l|c|c|c|c|}
\hline & Percentage & $\begin{array}{c}\text { Average cost } \\
\text { per meter }\end{array}$ & $\begin{array}{c}\text { Production cost } \\
\text { in Rs. 1000 }\end{array}$ & Year \\
\hline Bharuwa Dhaka-1 & 180.7 & 7 & 12,649 & \\
\hline Bunuwa Dhaka-1 & 108.7 & 10 & 1.807 & 1990 \\
\hline
\end{tabular}


The capacity of Dhaka textile producing units are the total production of all the units is estimated to be about 325600 meters.

(a) Bharuwa Dhaka is special type of weave used in caps, shawls, blouses etc. They are woven only in throw shuttle or fly shuttle hand looms. The only white threads are used in warp and in weft different coloured threads are woven by hand according to the design and the pattern. This is woven in throw shuttle loom in 6 inches wide size specially for the caps and in fly shuttle loom the cloth is woven 36 inches wide for caps, blouses or shawls, The production of this bharuwa Dhaka is $1 \%$ among the textile industry.

(b) Bunuwa Dhaka is specially used for expensive items like topi, cholo, khasto and expensive decoration like curtains table posh etc. The weaving has also speciality. This is also woven in throw shuttle of fly shuttle handlooms.

In western Nepal, mechanic station of Dhaka cloth weaving has demonstrated that there is a market for mass produced inlay Dhaka cloth but it is also apparent that there is an expanding market for the inimitable individually woven Dhaka cloth strips from the Kosi hills; the demand is local and from Tourists and overseas. Many weavers shows are beginning to take up weaving again since there is a many wider market for this high quality cloth.

\section{WORKS CITED}

Benjade, S. 1998. Participation Women in Dhaka Cloth Industry (Tansen) M.A. Thesis. Tribhuvan University Kirtipur, Kathmandu, Nepal.

Shrestha, E. 1995. Study on the Prospects of Promoting Dhaka Cloth Production in Nepal Research Report, submitted to Research Division, Tribhuvan University Kirtipur, Kathmandu, Nepal.

Shrestha E. 2060. A Study of Textile Looms in Kathmandu Valley. Research Report, submitted to University Grant Commission, Baneswar, Kathmandu, Nepal. 